\title{
Facilitation of tolaasin-induced hemolysis by phospholipids composed of medium-chain fatty acids
}

\author{
Yeong-Bae Yun ${ }^{1} \cdot$ Min-Hee Kim ${ }^{1} \cdot$ Young-Kee Kim $^{1}$ \\ 중간크기 탄소사슬의 지방산으로 이루어진 인지질에 의한 \\ tolaasin의 용혈활성 촉진
}

윤영배 $^{1} \cdot$ 김민희 ${ }^{1} \cdot$ 김영기 $^{1}$

Received: 17 May 2016 / Accepted: 20 May 2016 / Published Online: 30 September 2016

(C) The Korean Society for Applied Biological Chemistry 2016

\begin{abstract}
Tolaasin is a pore-forming peptide toxin produced by Pseudomonas tolaasii and causes a brown blotch disease by disrupting membrane structures of cultivated mushrooms. The mechanism and characteristics of tolaasin pore formation are not known in detail; however, tolaasin pores have been demonstrated in the artificial lipid bilayer. Since the tolaasin pore appeared less frequently and unstable in lipid bilayer, a mismatch between the length of tolaasin pore and the thickness of lipid membrane had been suggested. Therefore, tolaasin-induced hemolyses were measured by the additions of phospholipids composed of various fatty acids with different carbon numbers. When phosphatidylethanolamines made with two decanoic acids (C10:0, 1,2-didecanoyl-sn-glycero3-phosphoethanolamine; DDPE), myristic acids (C14:0, 1,2dimyristoyl-sn-glycero-3-phosphoethanolamine), and stearic acids (C18:0, 1,2-distearoyl-sn-glycero-3-phosphoethanolamine) were added to the buffer containing RBCs and tolaasin peptides, DDPE facilitated the tolaasin-induced hemolysis while the other two phospholipids showed no effects. At various concentrations of DDPE, the tolaasin-induced hemolysis was stimulated as a dosedependent manner. The phospholipids composed of medium-
\end{abstract}

Young-Kee Kim $(\bowtie)$

E-mail: ykkim10@cbnu.ac.kr

${ }^{1}$ Department of Environmental and Biological Chemistry, Chungbuk National University, Cheongju, Chungbuk 28644, Republic of Korea

This is an Open Access article distributed under the terms of the Creative Commons Attribution Non-Commercial License (http://creativecommons. org/licenses/by-nc/3.0/) which permits unrestricted non-commercial use, distribution, and reproduction in any medium, provided the original work is properly cited. chain fatty acids stabilize the tolaasin pore probably by binding between the pore structure and membrane phospholipids and making the membrane thickness thinner around the pore. These results showed that tolaasin molecules make more stable pores in the membrane made with phospholipids composed of medium length fatty acids, suggesting that the length of tolaasin pore is a little shorter than the thickness of RBC membrane.

Keywords Medium-chain fatty acid Peptide toxin - Pore formation - Pseudomonas tolaasii . Thickness of tolaasin pore Tolaasin

\section{서 론}

갈반병은 세계적으로 양송이와 느타리버섯을 포함한 버섯 재배 에 큰 해를 끼치는 질병으로 오래 전부터 알려져 왔다(Tolaas 1915). 버섯을 재배하는 버섯 농가에서 세균성 갈반병이 한번 발생하면 이를 통제하는 것은 매우 어려우며, 빠르게 재배농장 전체로 번지거나 다른 버섯 농가로 퍼져 나가게 되어, 버섯 농 가의 소득을 감소시키는 중요한 원인이 된다.

버섯의 갈반병은 Pseudomonas tolaasii에 의해 발생하는 것 이 확인되었으며, 이 병원균은 세포독성을 갖는 펩티드 독소인 tolaasin을 생성한다(Peng 1986). Tolaasin은 18개의 아미노산과 $\mathrm{N}$-말단의 작은 지방산으로 이루어진 lipodepsipeptide 독소로서, 분자량은 $1,985 \mathrm{Da}$ 이다. Tolaasin의 1차 구조는 1991년 Nutkins 등에 의해 밝혀져(Nutkins 등, 1991), 펩티드의 $\mathrm{N}$-말단이 acylation에 의해 $\beta$-hydroxyoctanoic acid와 결합하고 있고, C- 
말단의 lysine 잔기는 14 번째에 있는 D-allo-threonine과 lactone ring을 형성하는 복잡한 구조를 갖는다(Shirata 등, 1995; Bassarello 등, 2004). 이후, tolaasin의 다양한 동위체(analogue) 들이 발견되었으며 주로 한 개 이상의 아미노산이 치환되어 만 들어 지나, 이들의 세포독성은 밝혀지지 않았다. P. tolaasii 병 원균에 의한 tolaasin의 생성은 양분의 결핍이 일어나는 정체기 에 도달하면 증가하며, tolaasin은 직선형태의 peptide 전구체로 생성된다. 이후, 전구체는 특이적인 다양한 효소작용에 의하여 환상구조로 변환되며, 리보솜의 작용과 무관한 2 차대사산물이다 (Solar-Rivas 등, 1999).

Tolaasin의 작용기작은 숙주세포막에 pore를 형성하여 버섯 세 포를 파괴하는 것으로 pore-forming 독소임이 일찍부터 제안되 었다(Rainey 등, 1991; Hiep 등, 2008). 이 종류의 펩티드 독소 들은 수용성을 갖는 양친매성으로, target 세포의 막에 도달하면 세포막에 쉽게 삽입된다. 세포막에서 펩티드들은 다중체를 형성 하여 비선택성 양이온채널을 생성함으로써 삼투압교란을 통한 세포막의 파괴를 유발한다(Parker와 Feil 2005). 현재까지 tolaasin은 좌선성 $\alpha$-나선구조로 생체막과 상호작용함이 알려져 있고, 농도에 따라 낮은 농도에서는 pore 형성이, 높은 농도에 서는 계면활성제 특성으로 버섯의 세포막 구조를 붕괴시키는 것 으로 제안되었다. P. tolaasii의 배양액에서 분리한 tolaasin은 인 공지질이중막에서 두 가지 형태의 이온 채널을 형성함이 확인 되어 pore-forming 펩티드 독소로서의 작용기작이 확립되었다 (Cho와 Kim 2003).

세포막에 pore를 형성하여 독성을 나타내는 펩티드 독소는 일 반적으로, 세포막 결합, 분자다중체 형성에 의한 비선택성 pore 형성, 세포막 안팎의 전기화학전위 차이에 의한 막의 유동성 증 가, 삼투압 변화에 의한 세포의 파괴 단계로 독성을 나타낸다 (Shai 1999). Tolaasin에 의한 세포의 붕괴 또한 이러한 과정을 따를 것으로 알려져 있으며 지질이중막에서 tolaasin의 이온 채 널 형성을 확인함으로써 가능성을 확인하였다. 그럼에도 불구하 고 전기생리학적 방법을 사용하여 측정한 tolaasin의 pore는 불 안정하였고, 이러한 문제가 tolaasin 분자에 의해 생성되는 pore 의 길이와 지질막 두께 사이의 불일치로 인해 발생할 가능성이 확인되었다. Tolaasin 분자는 용액상에서 4 회전을 하는 좌선성 의 $\alpha$-나선을 형성하는데, 이는 tolaasin에 의해 생성되는 pore의 길이가 $20 \AA$ 에 가까워 일반적으로 알려진 세포막의 두께보다 짧 을 것으로 판단된다(Jourdan 등, 2003). 따라서, 본 연구에서는 tolaasin에 의해 생성되는 pore의 안정성과 이에 따른 세포독성 변화를 측정하기 위하여 다양한 탄소수로 이루어진 인지질을 첨 가하고 tolaasin의 세포독성을 측정하였다.

\section{재료 및 방법}

\section{Tolaasin의 분리}

Tolaasin의 분리는 Nutkins 등(1991)에 의한 방법을 약간 수정 하여 이루어졌다. P. tolaasii 6264 균주를 PAF 액체배지에서 접종한 후, $25^{\circ} \mathrm{C}$ 에서 18 시간 동안 정체기에 도달하도록 진탕 배양하였다. 배양액은 상온에서 $8,000 \mathrm{rpm}(10,000 \times \mathrm{g})$ 으로 30 분 간 원심 분리하여 세균을 제거하고 얻은 배양여액으로부터 crude tolaasin을 분리하였다(Cho 등, 2000). 이렇게 얻어진 tolaasin
용액에 $30 \%$ 가 되도록 ammonium sulfate를 가하고 $4^{\circ} \mathrm{C}$ 에서 1시간 동안 정치한 후, $\mathrm{SW} 28$ rotor (Beckman Instruments, Inc., Palo Alto, CA, USA)를 이용하여 20,000 rpm $(60,000$ $\times \mathrm{g}$ )에서 1 시간 동안 초고속 원심분리하였다. 침전으로 얻은 crude tolaasin은 HBS 완충액(pH 7.0) 또는 $10 \mathrm{mM}$ sodium phosphate 완충액 $(\mathrm{pH}$ 7.0)으로 녹이고, 실온에서 같은 용액으로 4시간 투석하여 Glass-Teflon homogenizer로 균질화한 후, aliquot을 만들어 액체질소로 급랭시키고 사용 전까지 $-60^{\circ} \mathrm{C}$ 의 초저온냉동고(deep freezer)에 보관하였다.

\section{적혈구 분리}

Diethyl ether를 이용하여 마취한 쥐를 개복하여 대정맥으로부터 채혈한 후, 멸균된 glass bead가 담긴 삼각 플라스크에 옮겨 약 1 시간 동안 교반하여 fibrin을 제거하였다. 얻어진 혈액은 150 $\mu \mathrm{L}$ 씩 분주하여 $4^{\circ} \mathrm{C}$ 에서 보관하였으며, 사용시에는 HEPESbuffered saline (HBS; $150 \mathrm{mM} \mathrm{NaCl}, 5 \mathrm{mM} \mathrm{KCl}, 5 \mathrm{mM}$ $\mathrm{HEPES}, 1 \mathrm{mM} \mathrm{MgSO}$, $\mathrm{pH}$ 7.4) 용액으로 10 배 희석하여 원심 분리로 온전한 적혈구만을 분리하여 사용하였다. 채취한 혈구는 약 3 주간 실험에 사용하였다.

\section{용혈활성 측정}

Tolaasin의 용혈활성은 Rainey 등(1991)의 방법에 따라 쥐의 적 혈구를 이용하여 측정하였다. 용혈활성 측정에 사용한 적혈구는 사용직전에 멸균한 $\mathrm{HBS}$ 완충액으로 10 배 희석하였고, 이것을 최종 반응 용액의 $10 \%$ 가 되도록 처리하였다. 용혈활성 측정 시 $1 \%$ 적혈구를 $37^{\circ} \mathrm{C}$ 에서 30 분 이내에 모두 용혈 시키는 톨 라신의 농도를 $1 \mathrm{HU}$ 으로 정하여 사용하였다. 용혈활성은 UV/ Vis spectrophotometer를 사용하여 $600 \mathrm{~nm}$ 에서 흡광도 변화로 측정하였다.

\section{인지질의 효과 측정}

Chloroform에 용해되어 있는 1,2-didecanoyl-sn-glycero-3-phosphoethanolamine (DDPE)와 1,2-dimyristoyl-sn-glycero-3-phosphoethanolamine (DMPE), 1,2-distearoyl-sn-glycero-3-phosphoethanolamine (DSPE)는 $\mathrm{N}_{2}$ gas를 이용하여 chloroform을 제거하고, 증류수에 용해하여 약 $2 \mathrm{mM}$ 의 stock solution으로 만들어졌다. 용혈활성 측정시, 제조한 lipid 용액을 전체 반응부피의 $10 \%$ 가 되도록 첨가하여 $200 \mu \mathrm{M}$ 농도가 되게 하였다. $600 \mathrm{~nm}$ 에서 흡광도를 측정함으로써 각각의 지질이 tolaasin의 용혈활성에 미치는 영 향을 관찰하였다.

\section{결과 및 고찰}

\section{크기가 다른 지방산으로 구성된 인지질의 효과}

Tolaasin에 의한 세포독성은 세포막에서 pore를 형성함으로써 일 어나며, tolaasin의 pore 형성작용에 미치는 다양한 인지질의 효 과를 측정하였다. 인지질은 탄소의 길이가 다른 포화지방산으로 구성된 것을 선택하였으며, 인지질 $\mathrm{DDPE}$ 는 2개의 decanoic acid (C10:0)를, DMPE는 myristic acid (C14:0)를, DSPE는 stearic acid (C18:0)를 각각 포함하는 phosphatidylethanolamine이며, 반 응 용액에 첨가하여 tolaasin의 용혈활성 특성을 측정하였다(Fig. 
1). DMPE와 DSPE를 첨가하였을 경우, tolaasin의 활성은 인지 질을 넣지 않은 대조구와 비교하여 차이가 없었으나, $\mathrm{DDPE}$ 를 첨가한 경우에는 5 분 이내에 적혈구의 용혈이 모두 일어나 tolaasin의 세포독성이 크게 증가하였다.

이러한 결과는 쥐의 적혈구 세포막을 구성하는 인지질이 탄 소수 18 개를 중심으로 $16-20$ 개의 탄소로 이루어진 지방산들로 구성되어 있다는 사실을 고려할 때(Bilgehan 2002), DMPE와 $\mathrm{DSPE}$ 는 세포막의 인지질들과 탄소사슬 길이에 큰 차이가 없어 tolaasin의 활성에 큰 영향이 없음을 보여준다. 반면, DDPE는 tolaasin의 활성을 크게 증가시켜, tolaasin에 의한 pore 형성을 촉진하거나 형성된 pore를 안정화시킴을 도와주는 역할을 하고 있음을 의미한다. 이는 tolaasin이 형성하는 pore의 길이가 적혈 구 세포막의 두께보다 짧아, 중간크기의 지방산으로 구성된 인 지질이 tolaasin pore의 주변에 결합하여 pore 뿐만 아니라 주 변 막의 안정성을 증가시킬 가능성이 있음을 확인할 수 있었다.

\section{DDPE의 사전처리에 따른 tolaasin의 용혈활성}

적혈구를 다양한 농도의 $\mathrm{DDPE}$ 에 10 분간 사전 배양하여 적혈 구 세포막에 $\mathrm{DDPE}$ 를 결합시킨 후, tolaasin 처리에 의한 용혈 활성은 대조실험에 비하여 빠르게 일어났다. DDPE 사전처리에 의한 tolaasin의 용혈활성 증가는 $\mathrm{DDPE}$ 의 처리농도에 따라 다 르나 $5 \mu \mathrm{M}$ 이상의 농도에서 증가하기 시작하여 $50 \mu \mathrm{M}$ 이상의 농도에서 최대로 나타났다(Fig. 2). 특히 $50 \mu \mathrm{M}$ 이상의 DDPE 와 적혈구가 사전 배양된 경우에는 tolaasin 첨가 후 10 분 이내 에 용혈이 완결되었다. 이러한 결과는 중간크기 사슬의 지방산 으로 이루어진 인지질이 tolaasin 분자의 빠른 pore 형성을 촉 진하여 tolaasin pore의 활성증가를 유발함을 알 수 있다.

\section{인지질과 tolaasin의 사전배양 후 용혈활성 측정}

다양한 지방산으로 이루어진 인지질과 tolaasin을 사전 배양한 후, 적혈구에 처리함으로써 tolaasin과 인지질의 상호작용 특성 을 조사하였다. 먼저, 쥐의 적혈구 세포막의 구성 인지질과 비 슷한 길이의 지방산들로 이루어진 인지질인 DMPE와 DSPE를 tolaasin에 사전처리하고 tolaasin의 용혈활성을 측정하였을 때, 용혈활성은 대조실험의 결과와 큰 차이를 보이지 않았다. 그러 나, tolaasin과 DDPE를 10 분간 사전 배양하여 적혈구에 처리하 였을 때, 대조실험 결과와 비교하여 tolaasin의 용혈활성은 크게 감소하였다(Fig. 3). 사전 배양한 tolaasin에 의한 용혈활성은 배 양시간 5 분에서 증가하기 시작하여, 10 분 후 부터는 완만하게 증가하여 30 분 후 최대치인 $60 \%$ 에 도달하여 대조실험과 같은 $100 \%$ 에는 도달하지 못하였다. 이것은 tolaasin과 DDPE가 사전 배양에서 서로 상호작용하여 응집체를 만들고 결과적으로 tolaasin이 적혈구의 파괴보다는 DDPE와 결합형태로 활성에 기 여하지 못함을 의미한다.

세 가지 인지질과 tolaasin의 사전배양 시간에 따른 용혈활성 변화를 측정하였다. 앞의 결과와 마찬가지로 DMPE와 DSPE는 사전배양 시간을 20 분까지 증가시켜도 tolaasin의 용혈활성에 영 향을 주지 않았다. 그러나, 중간길이의 지방산을 포함하는 인지 질 $\mathrm{DDPE}$ 는 사전배양 시간에 따라 tolaasin의 활성이 감소하여 5 분 후에 최대 저해를 보여 약 $40 \%$ 의 용혈활성이 감소하였다. 이후 20 분까지 배양시간을 증가하여도 저해 정도는 동일하였다 (Fig. 4). 이러한 결과는 다른 인지질에 비하여 DDPE가 tolaasin

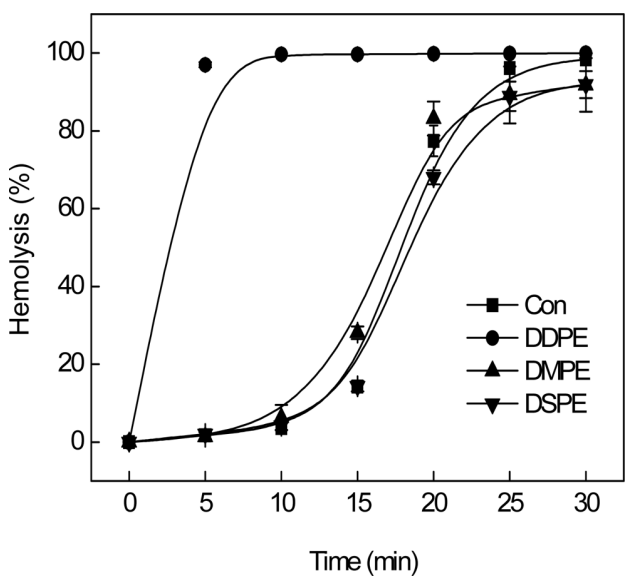

Fig. 1 Effects of various phospholipids on tolaasin-induced hemolysis. Tolaasin-induced hemolysis was measured in the presence of phopholipids composed of three different length of fatty acids, DDPE, DMPE, and DSPE. Time courses of hemolyses were measured after the additions of various phospholipids at $200 \mu \mathrm{M}$.

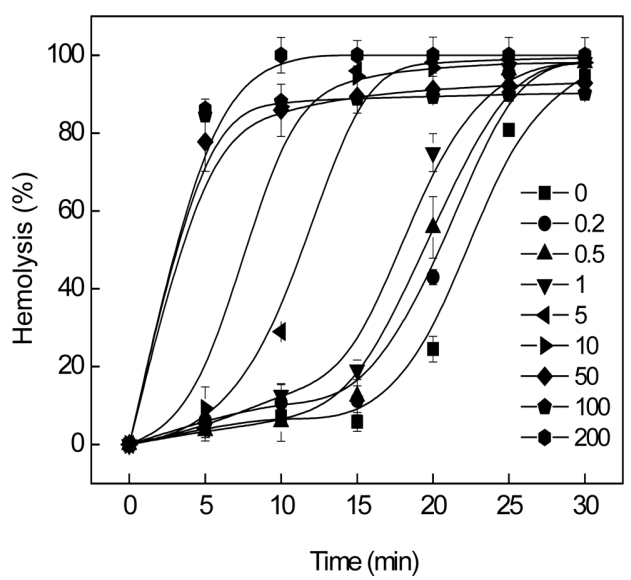

Fig. 2 Effects of preincubated DDPE on tolaasin-induced hemolysis. RBCs were preincubated at various concentrations of DDPE from 0.2 to $200 \mu \mathrm{M}$ for $10 \mathrm{~min}$. Tolaasin-induced hemolyses were measured after the addition of tolaasin at $1 \mathrm{HU}$.

펩티드와 특이적 상호결합력이 있어, 적혈구의 세포막으로 tolaasin 유입을 감소시켜 pore 형성을 저해하기 때문일 것이다. 한편, DMPE와 DSPE는 사전배양의 유무와 관계없이 tolaasin 에 의한 용혈에 영향을 주지 않음을 확인하였다. Tolaasin은 이 들과 결합하지 않거나 약하게 결합하여 쉽게 적혈구 세포막으 로 전이되므로 농도의 변화가 없는 것으로 여겨진다.

\section{DDPE의 농도변화에 따른 tolaasin의 용혈활성}

DDPE $200 \mu \mathrm{M}$ 을 tolaasin과 동시에 처리할 경우 tolaasin의 용 혈활성을 촉진하였고(Fig. 1), DDPE를 적혈구에 사전 처리하였 을 경우에도 tolaasin의 용혈활성은 크게 증가하였다(Fig. 2). 그 러나 DDPE를 tolaasin과 사전배양을 한 경우에는 tolaasin의 용 혈활성이 크게 저해되었다(Fig. 3). 이러한 결과는 적혈구 세포 


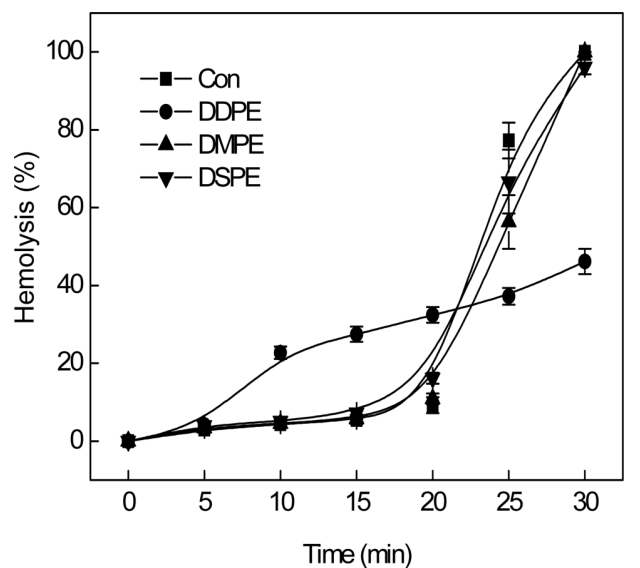

Fig. 3 Effect of preincubated tolaasin with phospholipids on hemolysis. Tolaasin and phospholipids were preincubated for $10 \mathrm{~min}$ before the addition of RBCs

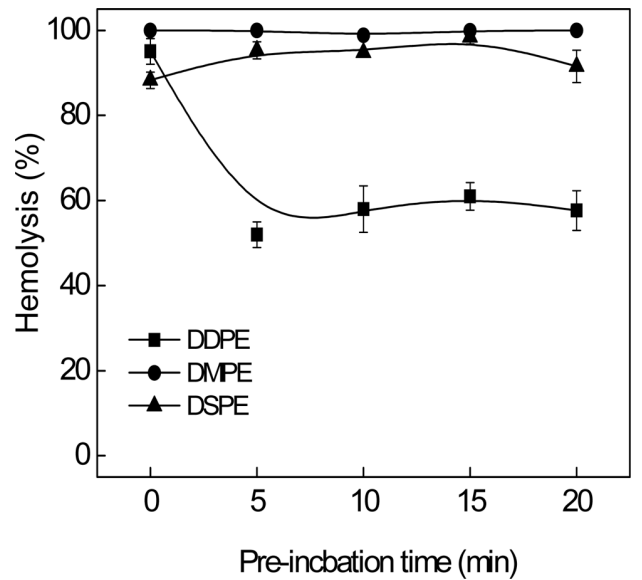

Fig. 4 Effect of preincubation between tolaasin and phospholipids on tolaasin-induced hemolysis. Tolaasins were preincubated with $200 \mu \mathrm{M}$ DDPE, DMPE, and DSPE for 10 min and added to RBC solution

막에 결합한 DDPE는 tolaasin의 pore 형성을 촉진하나, 사전배 양을 통하여 $\mathrm{DDPE}$ 와 tolaasin이 결합하면 적혈구 세포막에 미 치는 tolaasin의 용혈활성이 감소함을 의미한다. 이를 확인하기 위하여 DDPE의 농도 변화가 tolaasin의 용혈활성에 미치는 영 향을 측정하였다.

다양한 농도의 DDPE를 tolaasin과 사전 배양 없이 적혈구 용 액에 동시 첨가하였을 경우, $0.2-1 \mu \mathrm{M}$ 범위에서 용혈활성이 증 가하였으나, $5 \mu \mathrm{M}$ 과 $10 \mu \mathrm{M}$ 농도에서는 용혈활성이 감소하였고, 이보다 높은 $\mathrm{DDPE}$ 농도에서는 모두 용혈이 크게 증가하였다 (Fig. 5). 한편, DDPE와 tolaasin을 10 분간 사전 배양하여 적혈 구에 처리하였을 경우, 용혈활성이 저해되는 DDPE 농도가 약 20 배정도 높아진 $100 \mu \mathrm{M}$ 과 $200 \mu \mathrm{M}$ 에서 나타났으나, 이것은 용 혈활성 측정이 최종농도가 10 배 희석되므로 $10-20 \mu \mathrm{M}$ 에 해당 하여 동시 처리 조건과 크게 다르지 않다(Fig. 6). 이러한 결과 로 볼 때, 특정 농도의 DDPE는 오히려 tolaasin에 의한 용혈을 감소시킴을 알 수 있다.

이상의 결과는 decanoic acid를 함유하는 인지질이 tolaasin의

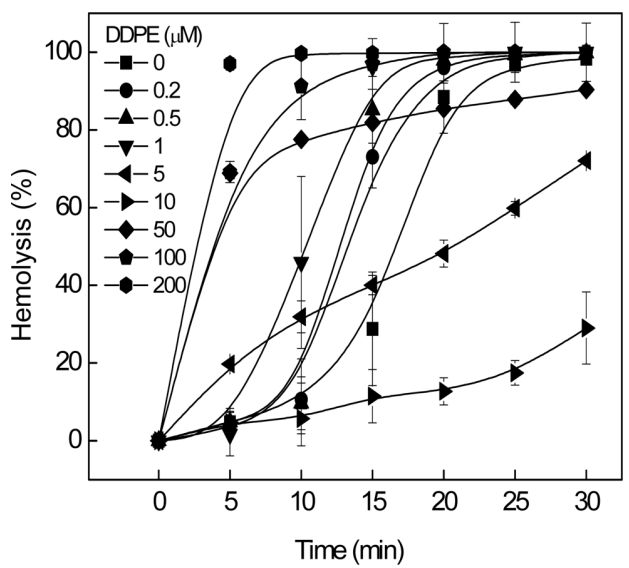

Fig. 5 Effects of DDPE on tolaasin-induced hemolysis. Tolaasin-induced hemolysis was measured in the presence of DDPE at various concentrations. Tolaasins, DDPE, and RBCs were mixed simultaneously

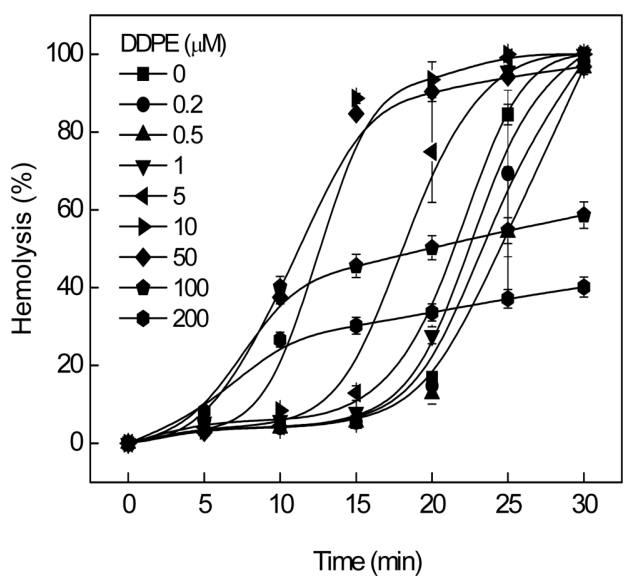

Fig. 6 Effect of preincubated tolaasin and DDPE on tolaasin-induced hemolysis. Tolaasins were preincubated at various concentrations of DDPE for $10 \mathrm{~min}$ and added to RBC solution

용혈활성에 미치는 다양한 특성을 조사한 것으로 $\mathrm{DDPE}$ 에 의 해 일어난 빠른 용혈현상은 인지질의 계면활성제 특성에 의해 서 나타날 수도 있겠으나(Chernitsky와 Senkovich 1997), 실제 $\mathrm{DDPE}$ 의 계면활성제로서 작용은 크지 않았다. Tolaasin을 제외 하고 DDPE 만을 처리한 경우 적혈구의 용혈은 관측되지 않았 으므로(자료 미제시), $\mathrm{DDPE}$ 의 효과는 인지질 자체가 적혈구에 영향을 미치는 것이 아니라 tolaasin의 이온채널 형성이나 활성 을 촉진하는 것으로 판단된다. 물론 tolaasin과 같은 펩티드 독 소들도 계면활성제 특성을 가지나(Bechinger와 Lohner 2006), 이것은 높은 농도에서 나타나는 특성으로 본 결과에는 해당하 지 않는다.

이상의 결과들은 tolaasin이 적혈구 세포막에서 형성하는 pore 의 길이가 세포막을 관통할 만큼 충분히 길지 않으며, 짧은 길 이의 지방산으로 구성된 인지질을 첨가할 때, 인지질 분자들은 tolaasin 분자들에 의해 생성된 pore의 주위에서 막의 두께를 감 소시켜 pore 자체를 안정화할 수 있음을 보여준다. 리포솜에서 합성된 이온채널의 길이에 따라 탄소수가 다른 지방산으로 이 
루어진 인지질이 이온채널의 활성을 최적화함은 제시된 바 있 어(Weber 등, 2005), tolaasin에 의해 생성된 pore도 주변에 몇 분자의 DDPE 결합에 의해 최적화될 수 있음을 알 수 있다.

한편, $5-10 \mu \mathrm{M}$ 의 $\mathrm{DDPE}$ 는 오히려 용혈을 저해하였으며, 이 것은 $\mathrm{DDPE}$ 와 tolaasin의 사전배양 시에도 유사하게 관측되었다. $\mathrm{DDPE}$ 가 저해효과를 보이는 것은 이 농도에서 DDPE가 micelle 을 형성하고 여기에 tolaasin이 결합하여 안정화된다면, 적혈구 막에 결합하는 tolaasin의 유효 농도가 감소하고 이것은 pore 형 성을 저해하여 결국 적혈구의 용혈이 감소할 것으로 예측된다. 특히, 짧은 지방산을 구성분으로 하는 인지질은 micelle 형성농 도인 $\mathrm{cmc}$ 는 상대적으로 높은 농도이며, 인지질의 지방산 부위 와 전하를 갖는 부위의 특성에 따라 다름이 밝혀져 있어 (Weschayanwiwat 등, 2005), 본 연구에서 사용한 특정농도의 DDPE가 반응용액 내에서 micelle을 형성하여 tolaasin 분자와 결합함으로써 유효농도를 감소시켜 활성이 감소하는 것으로 예 측된다.

\section{초 록}

Tolaasin은 Pseudomonas tolaasii에 의해 생성되어 pore를 형성 하는 펩티드 독소이며, 인공재배 버섯의 막 구조를 파괴하여 갈 반병을 일으킨다. Tolaasin이 막에서 pore를 형성하는 기작이나 특성은 자세히 알려지지 않았으나, 인공 지질이중막에서 tolaasin 에 의한 pore 형성은 제시되었다. Tolaasin에 의한 지질막에서 의 pore 형성은 드물게 나타났고, 형성된 pore는 불안정하기에 tolaasin pore의 길이와 지질막의 두께가 서로 일치하지 않을 수 있음이 제안되었다. 그러므로, 탄소수가 다른 지방산으로 이루어 진 인지질들을 첨가하여 tolaasin에 의한 용혈활성 변화를 측정하 였다. 두 개의 decanoic acids (C10:0, 1,2-didecanoyl-sn-glycero3-phosphoethanolamine; DDPE)와 myristic acids (C14:0, 1,2dimyristoyl-sn-glycero-3-phosphoethanolamine), stearic acids (C18:0, 1,2-distearoyl-sn-glycero-3-phosphoethanolamine)로 이루 어진 phosphatidylethanolamine들을 적혈구와 tolaasin 펩티드가 포함된 반응용액에 가했을 때, DDPE만이 tolaasin에 의한 용혈 활성을 촉진하였으며, 나머지 두 인지질은 효과를 보이지 않았 다. DDPE를 다양한 농도로 처리하였을 때, tolaasin에 의한 용 혈활성은 농도의존적으로 증가하였다. 중간길이의 지방산으로 구성된 인지질은 tolaasin pore 구조와 막지질 사이에 결합하여 pore 주변의 막을 얇게 함으로써 tolaasin pore를 안정화시킬 것 으로 여겨진다. 본 연구의 결과는 중간 크기의 지방산으로 구 성된 인지질이 tolaasin pore를 막 구조에서 안정화시킴으로써 활성을 증가시키며, 이것은 적혈구 막에서 tolaasin pore의 길이 가 막의 두께보다 조금 짧을 것이라는 사실을 제안한다.

Keywords 중간길이 지방산 - 펩티드독소 - pore 형성 Pseudomonas tolaasii · tolaasin · tolaasin pore의 두께

감사의 글 본 연구는 농림축산식품부 농생명산업기술개발사업 및 2014학 년도 충북대학교 학술연구지원사업의 연구비 지원에 의하여 이루어졌습니다.

\section{References}

Bassarello C, Lazzaroni S, Bifulco G, Lo Cantore P, Iacobellis NS, Riccio R, Gomez-Paloma L, Evidente A (2004) Tolaasins A-E, five new lipodepsipeptides produced by Pseudomonas tolaasii. J Nat Prod 67: 811-816

Bechinger B, Lohner K (2006) Detergent-like actions of linear amphipathic cationic antimicrobial peptides. Biochem Biophys Acta 1758: 15291539

Bilgehan DP (2002) Fatty acid composition of red blood cell membrane phosphatidylethanolamine and phosphatidylcholine in rat, rabbit, human, and dog. J Fac Pharm Ankara 31: 169-182

Chernitsky EA, Senkovich OA (1997) Erythrocyte hemolysis by detergents. Membr Cell Biol 11: 475-485

Cho KH, Kim YK (2003) Two types of ion channel formation of tolaasin, a Pseudomonas peptide toxin. FEMS Microbiol Lett 221: 221-226

Cho KH, Park KS, Kim YK (2000) Hemolytic properties of tolaasin causing the brown blotch disease on oyster mushroom. J Kor Soc Agric Chem Biotechnol 43: 190-195

Hiep HM, Endo T, Saito M, Chikae M, Kim DK, Yamamura S, Takamura Y, Yamiya E (2008) Label-free detection of melittin binding to a membrane using electrochemical-localized surface plasma resonance. Anal Chem 80: 1859-1864

Jourdan F, Lazzaroni S, Mendez BL, Cantore PL, Julio M, Amodeo P, Iacobellis NS, Evidente A, Motta A (2003) A left-handed $\alpha$-helix containing both L- and D-amino acids: The solution structure of the antimicrobial lipodepsipeptide tolaasin. Proteins: Struct Funct Genet 52: 534-543

Nutkins JC, Mortichire-Smith RJ, Packman LC, Brodey CL, Rainey PB, Johnstone K, Williams DH (1991) Structure determination of tolaasin, an extracellular lipodepsipeptide produced by the mushroom pathogen Pseudomonas tolaasii Paine. J AM Chem Soc 113: 2621-2627

Parker MW, Feil SC (2005) Pore-forming protein toxins: from structure to function. Prog Biophys Mol Bio 88: 91-142

Peng JT (1986) Resistance to disease in Agaricus bisporus (Lange) Imbach. Dissertation, University of Leeds

Rainey PB, Brodey CL, Johnstone K (1991) Biological properties and spectrum of activity of tolaasin, a lipodepsipeptide toxin produced by the mushroom pathogen Pseudomonas tolaasii. Physiol Mol Plant Pathol 39: 57-70

Shai Y (1999) Mechanism of the binding, insertion, and destabilization of phospholipid bilayer membrane by $\alpha$-helix antimicrobial and cell nonselective membrane-lytic peptides. Biochem Biophys Acta 1462: 55-70

Shirata A, Sugaya K, Takasugi M, Monde K (1995) Isolation and biological activity of toxins produced by a Japanese strain of Pseudomonas tolaasii, the pathogen of bacterial rot of cultivated oyster mushroom. Ann Phytopathol Soc Jpn 61: 493-502

Solar-Rivas C, Jolivet S, Arpin N, Olivier JM, Wichers HJ (1999) Biochemical and physiological aspects of brown blotch disease of Agaricus bisporus. FEMS Microbiol Rev 23: 591-614

Tolaas AG (1915) A bacterial disease of cultivated mushrooms. Phytopathol 5: $51-54$

Weber ME, Schlesinger PH, Gokel GW (2005) Dynamic assessment of bilayer thickness by varying phospholipid and hydraphile synthetic channel chain lengths. J Am Chem Soc 127: 636-642

Weschayanwiwat P, Scamehorn JF, Reilly PJ (2005) Surfactant properties of low molecular weight phospholipids. J Surf Deterg 8: 65-72 